\title{
Location and Characterization of Breeding Sites of Solitary Desert Locust Using Satellite Images Landsat 7 ETM+ and Terra MODIS
}

\author{
Lazar Mohammed ${ }^{1}$, Aliou Diongue ${ }^{2}$, Jeng-Tze Yang ${ }^{3 *}$, Doumandji-Mitiche Bahia4, \\ Lecoq Michel $^{5}$ \\ ${ }^{1}$ Institut National de la Protection des Végétaux, Alger, Algérie \\ ${ }^{2}$ United Nations World Food Programme, Dakar, Sénégal \\ ${ }^{3}$ National Chung-Hsing University, Taichung, Taiwan \\ ${ }^{4}$ Ecole Nationale Supérieure Agronomique, Alger, Algérie \\ ${ }^{5}$ CIRAD, Montpellier, France \\ Email: lazar.mohammed@gmail.com, aliou.diongue@wfp.org, "ityang@dragon.nchu.edu.tw, \\ Doumandjimitiche@yahoo.fr, lecoq@cirad.fr
}

Received 13 December 2014; accepted 6 January 2015; published 16 January 2015

Copyright (C) 2015 by authors and Scientific Research Publishing Inc.

This work is licensed under the Creative Commons Attribution International License (CC BY).

http://creativecommons.org/licenses/by/4.0/

(c) (i) Open Access

\begin{abstract}
In the southern Algerian Sahara, populations of the desert locust have been monitored during the past 43 years. On a limited study area, the use of remote sensing data from Landsat 7 ETM+ and Terra MODIS, coupled with the locust population database, allowed the identification and mapping of solitary desert locust breeding areas during remission periods. These sites are mainly located in wadis and in areas of accumulation/spreading of rainwater. The use of this methodology to all the Algerian Sahara is surely possible in order to improve the preventive management of this pest.
\end{abstract}

Keywords

Desert Locust, Schistocerca gregaria, Remote Sensing, Modis, Landsat, Early Warning

\section{Introduction}

The desert locust, Schistocerca gregaria (Forskål, 1775), is a dreaded insect because of the extent of damage it can inflict on agricultural production and of the socio-economic disruptions that may result [1] [2]. The consequences of its invasions can be disastrous for food security of many states in affected areas in Africa and Asia [3]. In addition, large amounts of chemical insecticides commonly used for control operations can result in se-

${ }^{*}$ Corresponding author.

How to cite this paper: Lazar, M., Diongue, A., Yang, J., Doumandji-Mitiche, B. and Lecoq, M. (2015) Location and Characterization of Breeding Sites of Solitary Desert Locust Using Satellite Images Landsat 7 ETM+ and Terra MODIS. Advances in Entomology, 3, 6-15. http://dx.doi.org/10.4236/ae.2015.31002 
rious damage to the environment [4]. Respectively 26 and 13 million hectares have been treated to stop the last two major invasions of 1987-1988 and 2003-2004 [5].

The natural risk posed by these locust invasions can be effectively managed by the application of a preventive control strategy based, in particular, on the monitoring of potential risk areas, the outbreak areas [6] [7]. It is within these gregarious areas that conditions favorable for the departure of an outbreak and an invasion are most frequently encountered. The preventive control strategy involves early warning and rapid response capacities of all the countries with outbreak areas of this locust. This involves the regular monitoring of environmental conditions in outbreak areas, the estimation of the level of locust populations, as well as the implementation of preventive control measures against the very first gregarious populations. This strategy was recommended by the Food and Agriculture Organization of the United Nations (FAO) as early as the 1960s [8]-[13]. The required capacities have been developed gradually and implemented - to varying degrees — in most countries with outbreak areas [1] [2]. In parallel and gradually, the areas to be monitored have been reduced from 31 million $\mathrm{km}^{2}$ of the invasion area to 15 million $\mathrm{km}^{2}$ of the recession area and $250,000 \mathrm{~km}^{2}$ of the outbreak areas. It has moved from a large area where all efforts may seem vain, to a much smaller area where the implementation of a preventive strategy becomes possible [7].

However, access to these areas located in the Saharan zone is difficult, and the areas to be monitored are still very large. The main concern of desert locust control units is to do this monitoring in the shortest time by optimizing routes prospecting of ground crews [14]. Early identification of breeding (maturation of groups of solitary adults as a result of favorable ecological conditions, egg laying and hopper development) is particularly crucial to have a chance to conduct effective preventive treatments before the first gregarious swarms disperse [6].

The use of satellite remote sensing technology has raised many hopes for forty years to support locust monitoring [15]-[20]. The research has focused mainly on locust species worldwide, Locusta migratoria [21], Chortoicetes terminifera [22], Rhammatocerus schistocercoides [23] and Nomadacris septemfasciata [24], but also on various grasshoppers species [3] [25]. For the desert locust, these techniques can in theory allow researchers, firstly, to better locate and map potential areas for reproduction and gregarization, and secondly, to identify in real time the appearance in these areas of suitable ecological conditions for breeding (rain, runoff and development of green vegetation), well before the first signs of gregarization [7] [26]. To date, however, there is no direct operational application based on remote sensing to guide ground surveillance teams of the desert locust [27].

Various studies are underway to try to improve the real-time detection of favorable ecological conditions, mainly green vegetation. These studies are based on Terra-MODIS and SPOT-VEGETATION images [28], and they try to solve problems related to low vegetation cover in Saharan environments [29]. In addition, all areas, even covered with vegetation, are not all equally favorable. The most potentially suitable habitats are grouped within the outbreak areas and represent a small fraction of those areas. Regarding mapping of the potentially favorable areas, some studies using high-resolution satellite imagery (1 pixel $=20 \mathrm{~m}$ side) have resulted in a spatial delineation of habitats of the desert locust. The works of Dreiser [30], Voss and Dreiser [31] and Dreiser et al. [32]-[35] based on analysis of Landsat images provide a first attempt to map locust habitats. However, these maps are not related to the probability of reproduction and gregarization of solitary populations. It is more maps of vegetation development at a given time and not real maps of locust habitats. Any operational use is illusory. Habitat maps of the desert locust by Popov [36] were designed thanks to the large field experience of this scientist, but without use of satellite imagery. Recently, Piou et al. [37] analyzed, in Mauritania, the relationship between historical prospection data of desert locust observations from 2005 to 2009 and spatio-temporal statistics of a vegetation index (NDVI) gathered by remote-sensing (MOD13Q1 from MODIS satellite) with the help of multiple models of logistic regression. The multi-model framework showed that vegetation development in a month and a half before the survey was amongst the best predictors of locust presence.

The main objective of this work, carried out on a pilot area in southern Algerian Sahara, is to integrate data from locust monitoring during the past 43 years, with remote sensing multispectral data of high resolution to locate, characterize and map the main breeding areas of solitary populations during remission periods, and thus to highlight the main sites to be preferentially monitored - if ecological conditions become favorable-through prevention operations during remission periods.

\section{Methodology}

\subsection{Study Area}

A pilot area was chosen for this study in the southwest of the Hoggar, in the region of Tamanrasset, which con- 
tain the largest number of square degrees with a high frequency of reproduction of the desert locust in its solitary phase (Figure 1). The pilot study is a permanent habitat for the desert locust.

\subsection{Locust Data}

The National Institute of Plant Protection performs regular monitoring of desert locust populations across the Algerian territory and especially throughout the recession area located in the Saharan zone. Data collected are density and age of locust populations, their phasis status (solitarious, transient, gregarious) and some environmental parameters particularly vegetation. These data are stored in the RAMSES database (Reconnaissance and Monitoring System of the Environment of Schistocerca) implemented by desert locust Information Service of FAO [38] in all the countries concerned by desert locust survey and preventive control. RAMSES is a computerized GIS-based application through which any user can store, view and retrieve desert locust related information at a national scale. This RAMSES basis for Algeria has more than 35,000 records resulting from surveys carried out in the field from 1965 to 2008. Data refer to geographical location of the surveyed areas (geographic coordinates), locust populations (density, biological state, phasis status) and various environmental parameters. From this basis it was possible to identify and map all the sites where reproduction of solitary populations were observed (only the egg laying females, hoppers as well as control operations against concentrations of solitary locust populations were used as an index of breeding).

\subsection{Satellite Data}

Satellites data of March 2005 issued from Landsat 7 ETM+ (Enhanced Thematic Mapper Plus) and from Terra Modis (Moderate-resolution Imaging Spectroradiometer) have been downloaded from the following sites: http://glcf.umd.edu/data/landsat//and http://iridl.ldeo.columbia.edu/maproom/Food_Security/Locusts/index.html. Mapping and satellite image processing were performed by the software ENVI 4.6 and ArcView 3.4. The base map used is from the National Geographic Institute (IGN) in Paris at the scales of 1:1,000,000 and 1:500,000.

\subsection{Data Analysis}

The difficulties related to the spectral characteristics of desert environments have necessitated the development of a specific methodology to bring out the breeding sites of the desert locust in its solitary phase. Vegetation was not useful as, in arid areas, it has often a reduced photosynthetic activity. Some dry years, there is virtually no

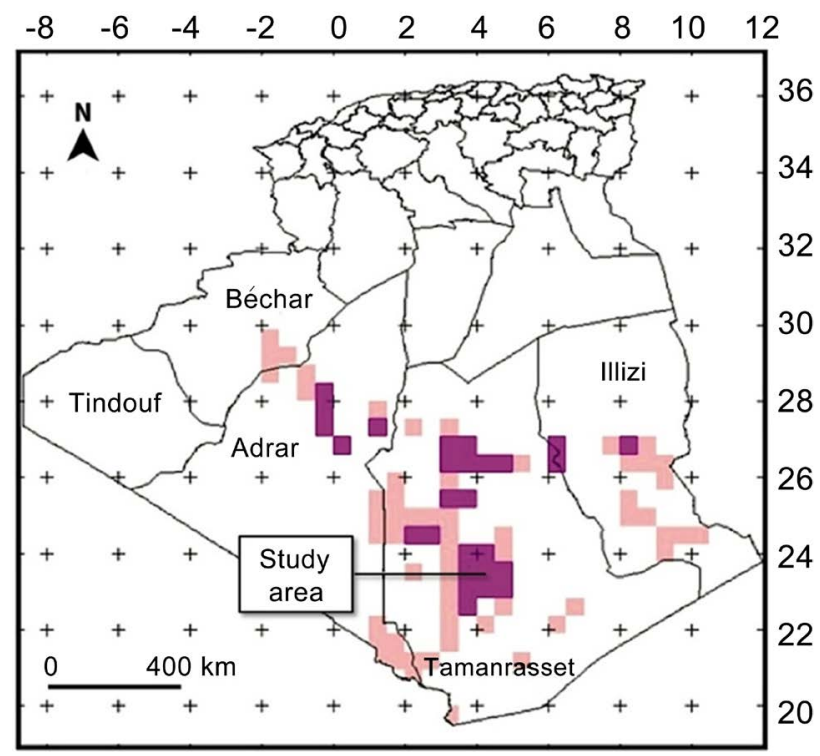

Figure 1. Distribution of quarter degree squares with a high frequency of reproduction of solitary locust populations (dark pink: high frequency; light pink: average frequency). 
herbaceous annuals (coverage rate close to zero), and woody perennial species remain dry for months. And thus, for locust breeding areas there is rarely a specific spectral pattern. To overcome the difficulties in vegetation mapping, we looked for correlations between the breeding zones of solitary locusts (identified from the RAMSES database) and some easily identifiable geomorphological features using satellite imagery (Figure 2). However, the desert areas are characterized by soils generally highly reflective, mainly composed of silica sand and of limestone or gypsum fragments. In addition, they are often dry in surface. For this reason, it was impossible to separate the egg laying sites from other desert habitats (sand dunes, rocky plateaus, bare soil) from a simple classification (supervised or not) because of the reflectance values almost identical for the various layers (Figure 3). For all these reasons, and in order to overcome the difficulties related to the nature of the desert, mapping of breeding and egg laying sites required the use of both Terra MODIS and Landsat 7 ETM+ data, and specific digital treatments to optimize satellite images display. The various treatments carried out and the results obtained are described below.

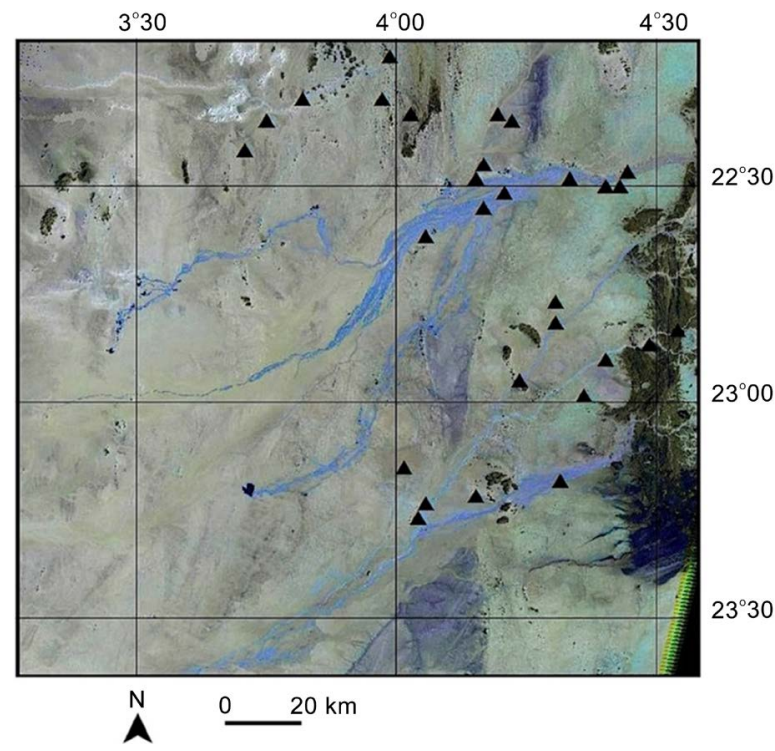

Figure 2. Location of breeding sites on an image of Landsat 7 ETM+ of the study area. The triangles represent sites where solitary laying females were observed during the past 43 years $(1965-2008)$.

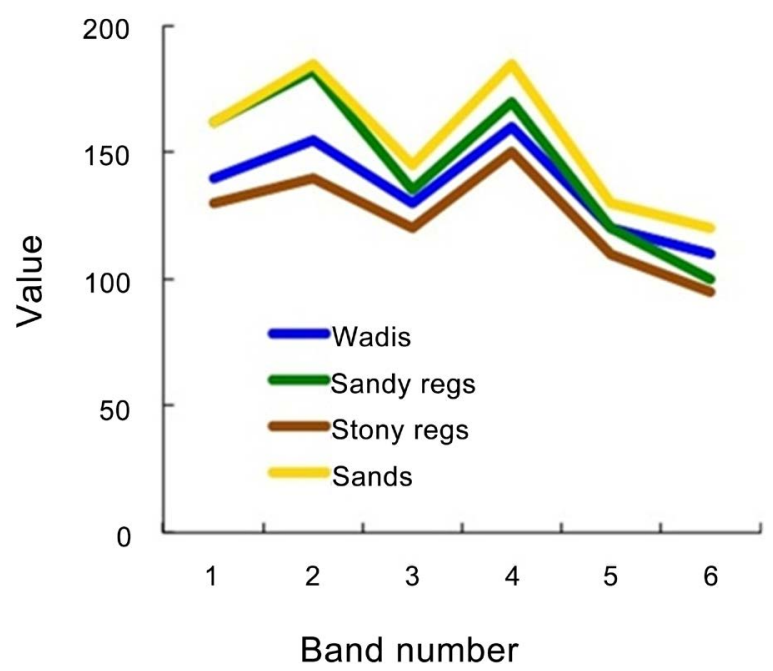

Figure 3. Spectral profiles determined from Landsat 7 ETM+ on wadis, stony regs, sandy regs and sandy soils. 


\section{Results}

In the Saharan zone, it is known that the presence of various mountain ranges proves to be crucial to the locust by the wadis networks associated [39]. These wadis concentrate rainwater and can create conditions for locusts breeding, and this even in case of light rains. Thus, the main mountain ranges that form the main water supply of breeding areas for solitary populations of desert locust in southern Algeria were first mapped by using MODIS images at $250 \mathrm{~m}$ resolution. The technique of equal density classes was applied to the MODIS image in order to transform grayscale areas into colour ranges. This treatment transforms the image into RGB (red, green, blue) areas where similar spectral behavior appears in the same color. The highest mountain ranges were displayed with the same color. This color was transformed into a vector, exported and overlaid on a topographic map for identification of mountains ( 6 in total: 4 in the center of the Algerian Sahara, 1 at the border with Mali and 1 at the border with Niger) (Figure 4).

The breeding sites of solitary desert locusts were then superimposed on the map of the mountains. These sites are grouped into 85 quarter degree squares with an annual breeding frequency high or very high. This overlay allowed identifying five breeding areas under the influence of mountains: Hoggar, Ahnet and Assedjrad, Mouydir, Tassili n'Ajjer, and Adrar des Iforas (Figure 4). This location of high frequency breeding areas near the mountains is logically explained by the fact that the hydrographic network and the wadis with sandy soil or sandy-clay soils favor locust breeding. These wadis become favorable for breeding when they receive and accumulate rainwaters from the mountains.

The Landsat 7 ETM+ data were then used to map geomorphologic features and to especially identify the wadis where the breeding sites of solitary desert locusts are located. Several treatments have been necessary to separate wadis from other geomorphological structures due to the similarity of their reflectance. The six bands of Landsat 7 ETM+ were first loaded and displayed in composite color using channels 4, 3 and 2, respectively, infrared, red and green (Figure 5). A principal component analysis on the six original bands of Landsat 7 ETM + has reduced the information contained in the six original bands, highly correlated, to only 3 components. This mathematical transformation produces a new image, accentuating the contrast of the original image, and making a much easier geomorphological interpretation (Figure 6).

A supervised classification allowed the extraction and mapping of the major wadis in the region (Figure 7). It is clear that the quarter degree squares with a high frequency of locust breeding are those containing many wadis and structures of various sizes (Figure 8). This layer "wadis" was then transformed into a vector, exported and superimposed on a topographical map for checking (Figure 9). We observed a perfect overlay of medium and large wadis mapped with those observed on the topographical map. Only small wadis were not visible on the satellite image, probably as a result of the low 30-meters resolution of Landsat 7 ETM+.

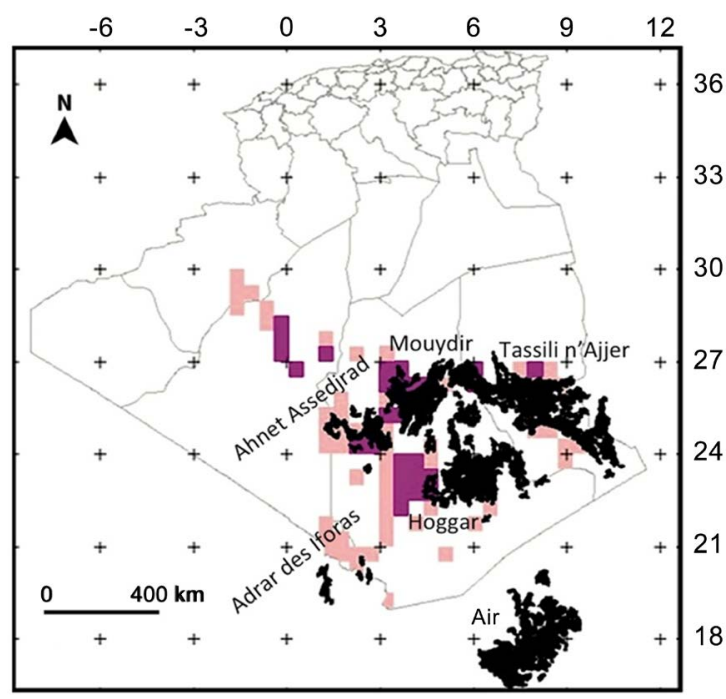

Figure 4. Location of egg laying sites of solitary desert locusts in the Algerian Sahara. Mountains are in black; breeding sites correspond to quarter degree squares coloured in light pink or dark pink. 


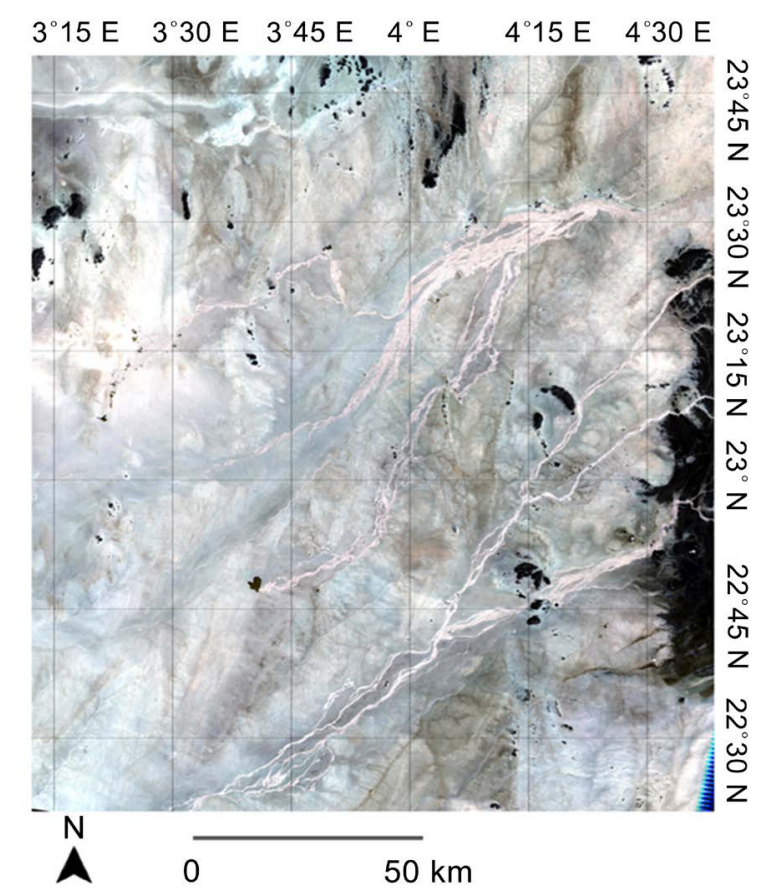

Figure 5. Colourful composition of bands 4, 3 and 2 of a Landsat 7 ETM+ image of 21 March 2005 in south western Hoggar (Tamanrasset region).

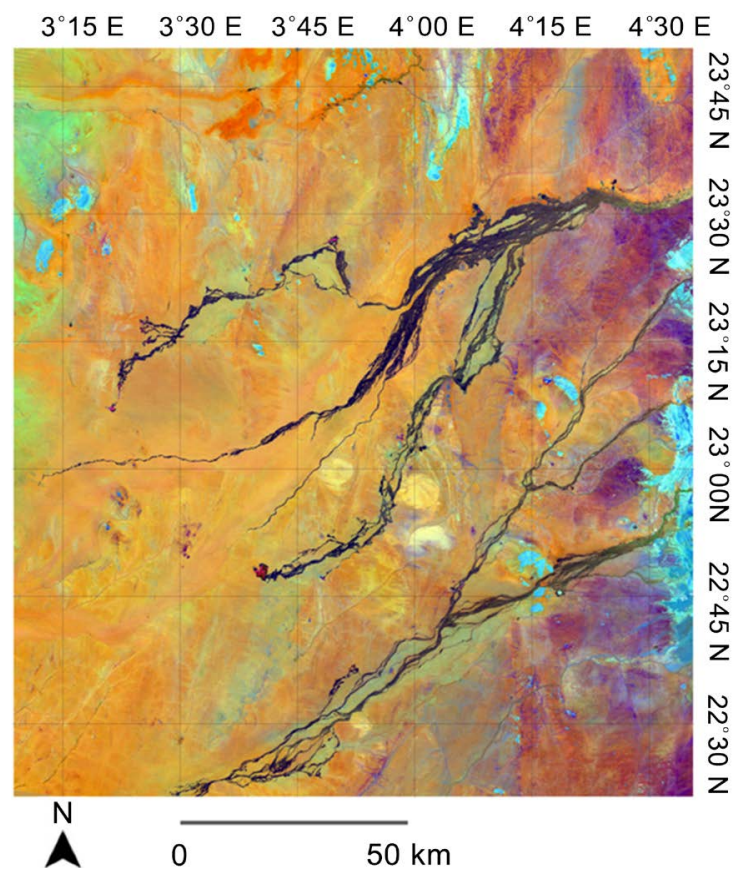

Figure 6. Image of the main component by treating 6 channels of the Landsat 7 ETM+ bands 1, 2, 3, 4, 5 and 7 in south western Hoggar (Tamanrasset region).

\section{Discussion}

This work shows the potential of Landsat 7 ETM+ images to map the main breeding areas of the desert locust in its solitary phase. Much work has been done in the past on the characterization of habitats of this species by the 


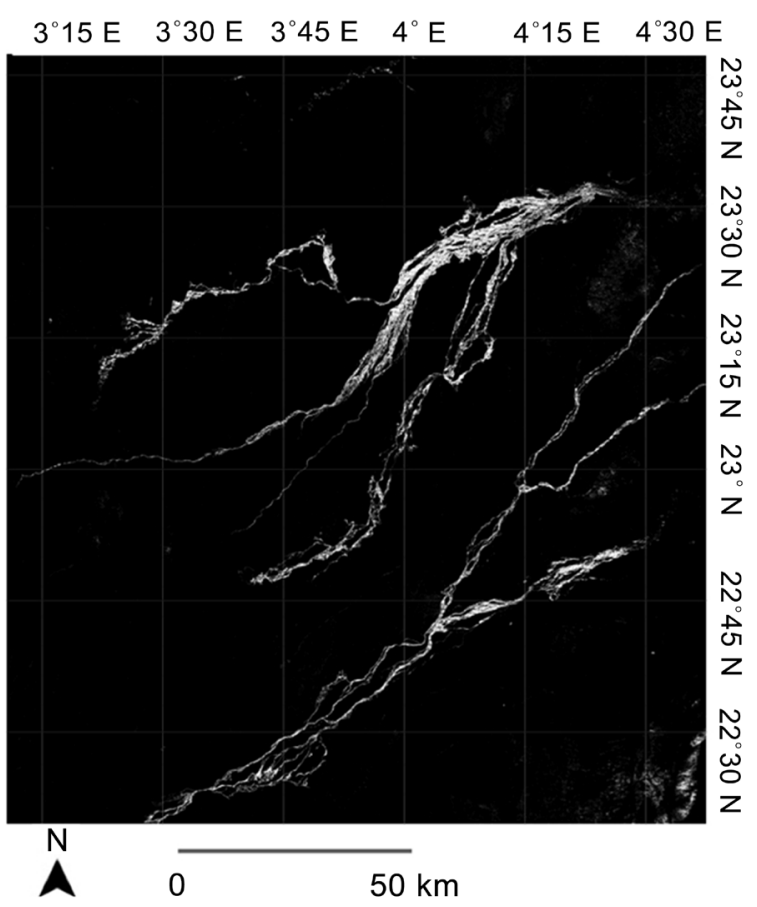

Figure 7. Extraction of the main wadis in the study area.

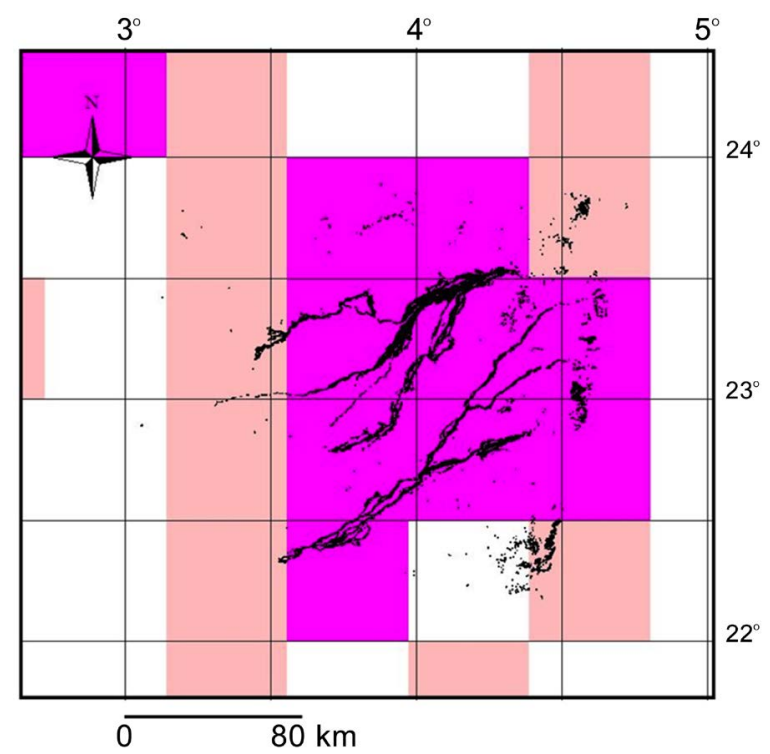

Figure 8. Overlay of the main wadis (obtained by analysis of satellite images) with the quarter degree squares of high (light pink) and very high (dark pink) breeding frequency of solitary locust populations.

use of remote sensing data. These studies have generally been based on attempts to map the vegetation (e.g. Dreiser et al. [32]-[35]). However, this mapping has proven to be difficult and costly. Indeed, in the Saharan region, the vegetation is difficult to identify due to a low coverage and often to a spectrum with no specific features [40]. In addition, extensive areas of vegetation vary from season to season and from year to year depending on rainfall, making illusory any attempt to map such an ephemeral parameter. It could never be better that a mere image at a given time. It seemed more useful to get rid of the vegetation and, using satellite imagery, to look for correlations between breeding areas of solitary locusts and some easily identifiable geomorphological features. 


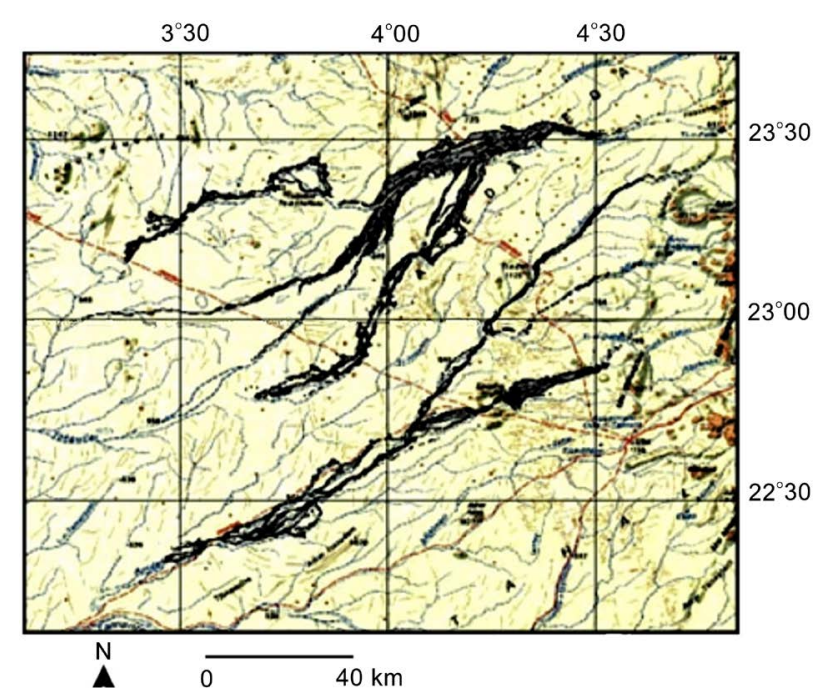

Figure 9. Overlay of a topographic map with the main wadis (in black), forming areas of potential locust breeding and highlighted by analysis of Landsat 7 ETM+ imagery.

In this context, the joint use of remote sensing data and of locust data issued from RAMSES for a period of 43 years (1965-2008) proved to be crucial. These locust data helped to prioritize the different areas according to their interest for the locust ecology. They allowed us to focus only on areas of major interest for the preventive control of this species. For our study area in the Hoggar, it's mainly the wadis on sandy, loam and clay-loam soils that gave the locust very favorable breeding conditions in case of rain or runoff. These wadis related to locust breeding have been fully mapped through various treatments applied mainly to data from Landsat 7 ETM .

The scale used in this study makes operational results. They can be a cartographic basis of the potential locust breeding areas to be monitored in priority, especially when favorable ecological conditions develop. These results can be used in a geographic information system as a static basis layer of potentially suitable habitats, which may be superimposed on the dynamic information on environmental conditions, in particular vegetation phenology and rainfall [29] [37] [41]. Thus, the areas favorable to locust activity could be better delineated in real time, allowing survey teams to monitor, detect and destroy the first locust outbreaks more efficiently, thus reducing the risk of an invasion.

The method should be extended to all gregarization areas in Algeria and probably to other countries in the region containing outbreak areas, particularly Libya, Mauritania, Mali, Niger and Chad. All these countries have the necessary data bases on desert locust (often several decades of observations) to locate, for solitary populations, breeding areas of high frequency. Landsat images are available for free. This generalization could be done with minimal cost. However, climate change may likely modify the location of these favorable habitats and it will be necessary to remain vigilant on this issue.

The extrapolation of the method to a larger area, however, may pose some difficulties that must be overcome. Indeed, locust archive data showed that while $81 \%$ of the females deposited their eggs in the wadis or their surroundings (these wadis have been the subject of this study), there were $19 \%$ of egg pods laid in other areas (non characterized in this first approach). The same problem may arise if our method is extrapolated to other regions. It will also be necessary, for these new areas, to check if it is possible to associate the areas of high breeding frequency of solitary populations with geomorphological features (wadis or others) easily identifiable by remote sensing. Nevertheless, despite the limitations, the aim of this study is not so much to map all of these areas than just the most important ones. This will allow quicker reaction with a better focus of the survey teams at the early stages of gregarization when small impacts on locust population size can have dramatic effects and populations are still contained locally [7].

\section{Acknowledgements}

The authors wish to thank the FAO Commission for controlling the desert locust in the Western Region (CLCPRO) 
who financially supported this study, and the National Institute for Plant Protection of Algeria who has provided

its data on desert locust and made all the necessary logistical and human support for the field works.

\section{References}

[1] Lecoq, M. (2001) Recent Progress in Desert and Migratory Locust Management in Africa. Are Preventative Actions Possible? Journal of Orthoptera Research, 10, 277-291. http://dx.doi.org/10.1665/1082-6467(2001)010[0277:RPIDAM]2.0.CO;2

[2] Lecoq, M. (2003) Desert Locust Threat to Agricultural Development and Food Security and FAO/International Role in its Control. Arab Journal of Plant Protection, 21,188-193.

[3] Latchininsky, A.V. (2013) Locusts and Remote Sensing: A Review. Journal of Applied Remote Sensing, 7, Article ID: 075099. http://dx.doi.org/10.1117/1.JRS.7.075099

[4] Brader, L., Djibo, H., Faye, F.G., Ghaout, S., Lazar, M., Nguala, P.M. and OuldBabah, M.A. (2006) Towards a More Effective Response to Desert Locusts and their Impacts on Food Insecurity, Livelihoods and Poverty. Independent Multilateral Evaluation of the 2003-05 Desert Locust Campaign. Food and Agriculture Organization of the United Nations, Rome.

[5] Lecoq, M. (2005) Desert Locust Management: From Ecology to Anthropology. Journal of Orthoptera Research, 141, 179-186. http://dx.doi.org/10.1665/1082-6467(2005)14[179:DLMFET]2.0.CO;2

[6] Magor, J.I., Lecoq, M. and Hunter, D.M. (2008) Preventive Control and Desert Locust Plagues. Crop Protection, 27, 1527-1533. http://dx.doi.org/10.1016/j.cropro.2008.08.006

[7] Sword, G.A., Lecoq, M. and Simpson, S.J. (2010) Phase Polyphenism and Preventative Locust Management. Journal of Insect Physiology, 56, 949-957. http://dx.doi.org/10.1016/j.jinsphys.2010.05.005

[8] FAO (1968) Desert Locust Project. Final Report. Report No. FAO/SF: 34/DLC. Food and Agriculture Organization of the United Nations, Rome.

[9] FAO (1972) Projet relatif au Criquet pèlerin. Rapport complémentaire (juillet 1966-décembre 1970). Report No. FAO/ SF: 34/DLC. Food and Agriculture Organization of the United Nations, Rome.

[10] Hafraoui, A. and McCulloch, L. (1993) Present Practices of Controlling Desert Locust Outbreaks. Food and Agriculture Organization of the United Nations, Rome.

[11] Krall, S., Peveling, R. and Diallo, D.B. (1997) New Strategies in Locust Control. Birkhäuser Verlag, Basel. http://dx.doi.org/10.1007/978-3-0348-9202-5

[12] Magor, J.I., Ceccato, P., Dobson, H.M., Pender, J. and Ritchie, L. (2005) Preparedness to Prevent Desert Locust Plagues in the Central Region: An Historical Review. Report No. AGP/DL/DS/35, Desert Locust Technical Series, Food and Agriculture Organization of the United Nations, Rome.

[13] Van Huis, A. (2007) Locust Control by Early Identification of Breeding Sites. Encyclopedia of Pest Management, 1, $1-3$.

[14] SidiBenahi, A.S. (2008) Délimitation spatial et temporelle des biotopes du Criquet pèlerin Schistocerca gregaria (Forskål, 1775) en Mauritanie (zone pilote de Grarat Levras). Master SILAT "Systèmesd' informations localisées pour l' aménagement des territories", ENGREF/AGRO/IGN/INA-PG, Montpellier, France.

[15] Cherlet, M.R., Di Gregorio, A. and Hielkema, J.U. (1991) Remote-Sensing Applications for Desert Locust Monitoring and Forecasting. EPPO Bulletin, 21, 633-642. http://dx.doi.org/10.1111/j.1365-2338.1991.tb01297.x

[16] Hielkema, J.U. (1977) Application of Landsat Data in Desert Locust Survey and Control. Food and Agriculture Organization of the United Nations, Rome.

[17] Hielkema, J.U. (1991) Desert Locust Monitoring with Satellite Remote Sensing. ITC Journal, 4, 387-417.

[18] Hielkema, J.U., Roffey, J. and Tucker, C.J. (1986) Assessment of Ecological Conditions Associated with the 1980/81 Desert Locust Plague Upsurge in West Africa Using Environmental Satellite Data. International Journal of Remote Sensing, 7, 1609-1622. http://dx.doi.org/10.1080/01431168608948956

[19] Pedgley, D.E. (1974) ERTS Surveys a $500 \mathrm{~km}^{2}$ Locust Breeding Site in Saudi Arabia. In: Frieden, S.C., Mercanti, E.P. and Becker, M.A., Eds., Third Earth Resources Technology Satellite - Symposium, Vol. 1, NASA, Maryland, 233-246.

[20] Tucker, C.J., Hielkema, J.U. and Roffey, J. (1985) The Potential of Satellite Remote Sensing of Ecological Conditions for Survey and Forecasting Desert-Locust Activity. International Journal of Remote Sensing, 6, 127-138. http://dx.doi.org/10.1080/01431168508948429

[21] Sivanpillai, R. and Latchininsky, A.V. (2007) Mapping Locust Habitats in the Amudarya River Delta, Uzbekistan, Using Multi-Temporal MODIS Imagery. Environmental Management, 39, 876-886.

http://dx.doi.org/10.1007/s00267-006-0193-y 
[22] Bryceson, K.P., Hunter, D.M. and Hamilton, J.G. (1993) Use of Remotely Sensed Data in the Australian Plague Locust Commission. In: Corey, S.A., Dall, D.J. and Milne, W.M., Eds., Pest Control and Sustainable Agriculture, CSIRO, Melbourne, 435-439.

[23] de Miranda, E.E., Pierozzi Jr., I., Batistella, M., Duranton, J.F. and Lecoq, M. (1994) Static and Dynamic Cartographies of the Biotopes of the Grasshopper Rhammatocerus schistocercoides (Rehn, 1906) in the State of Mato Grosso, Brazil. Technical Review for Ibero-American and Worldwide Integration, SELPER, 10, 67-71.

[24] Franc, A. (2007) Impact des transformations mésologiques sur la dynamique des populations et la grégarisation du criquet nomade dans le bassin de la Sofia (Madagascar). Unpublished Doctoral Thesis, University of Montpellier III, Montpellier.

[25] Latchininsky, A.V. and Sivanpillai, R. (2010) Locust Habitat Monitoring and Risk Assessment Using Remote Sensing and GIS Technologies. In: Ciancio, A. and Mukerji, K.G., Eds., Integrated Management of Arthropod Pests and Insect Borne Diseases, Integrated Management of Plant Pests and Diseases, Vol. 5, Springer, Dordrecht, 163-188.

[26] Cressman, K. (2013) Role of Remote Sensing in Desert Locust Early Warning. Journal of Applied Remote Sensing, 7 , Article ID: 075098. http://dx.doi.org/10.1117/1.JRS.7.075098

[27] Ceccato, P., Cressman, K., Giannini, A. and Trzaska, S. (2007) The Desert Locust Upsurge in West Africa (20032005): Information on the Desert Locust Early Warning System, and the Prospects for Seasonal Climate Forecasting. International Journal of Pest Management, 53, 7-13. http://dx.doi.org/10.1080/09670870600968826

[28] Ceccato, P. (2005) Operational Early Warning System Using SPOT-VGT and TERRAMODIS to Predict Desert Locust Outbreaks. In: Veroustraete, F. and Bartholomé, E., Eds., Proceedings of the 2nd International SPOT-VEGETATION Users Conference, European Commission, Office for Official Publication of the European Communities, Luxembourg, $475 \mathrm{p}$.

[29] Pekel, J.F., Ceccato, P., Vancutsem, C., Cressman, K., Vanbogaert, E. and Defourny, P. (2011) Development and Application of Multi-Temporal Colorimetric Transformation to Monitor Vegetation in the Desert Locust Habitat. IEEE Journal of Selected Topics in Applied Earth Observations and Remote Sensing, 4, 318-326. http://dx.doi.org/10.1109/JSTARS.2010.2052591

[30] Dreiser, U. (1994) Mapping of Desert Locust Habitats in Africa Using Landsat Thematic Mapper Data. GeoJournal, 32, 55-60. http://dx.doi.org/10.1007/BF00806357

[31] Voss, F. and Dreiser, U. (1997) Mapping of Desert Locust Habitats Using Remote Sensing Techniques. In: Krall, S., Peveling, R. and Ba Diallo, D., Eds., New Strategies in Locust Control, Birkhäuser Verlag, Basel, 37-45.

[32] Dreiser, U., Voss, F. and Popov, G. (1992) Potential Desert Locust Biotopes-Tokar Delta (Sudan). Mapsheet, GTZ, Eschborn.

[33] Dreiser, U., Voss, F. and Popov, G. (1993) Principaux biotopes du criquet pèlerin dans le nord du Tilemsi (Mali). Mapsheet, GTZ, Eschborn.

[34] Dreiser, U., Voss, F. and Popov, G. (1993) Principaux biotopes du criquet pèlerin dans l'Adrar des Iforhas (Mali). Mapsheet, GTZ, Eschborn.

[35] Dreiser, U., Voss, F. and Popov, G. (1994) Principaux biotopes du criquet pèlerin dans la région d'Akjoujt—Atar (Mauritanie). Mapsheet, GTZ, Eschborn.

[36] Popov, G.B. (1997) Atlas of Desert Locust Breeding Habitats. Food and Agriculture Organization of the United Nations, Rome.

[37] Piou, C., Lebourgeois, V., Benahi, A.S., Bonnal, V., el Hacen Jaavar, M., Lecoq, M. and Vassal, J.M. (2013) Coupling Historical Prospection Data and a Remotely-Sensed Vegetation Index for the Preventative Control of Desert Locusts. Basic and Applied Ecology, 14, 593-604. http://dx.doi.org/10.1016/j.baae.2013.08.007

[38] Cressman, K. and Hodson, D. (2009) Surveillance, Information Sharing and Early Warning Systems for Transboundary Plant Pests Diseases: The FAO Experience. Arab Journal of Plant Protection, 27, 226-232.

[39] Lecoq, M. (2012) Bioécologie du criquet pèlerin. FAO-CLCPRO (Food and Agriculture Organization of the United Nations - Commission for Controlling the Desert Locust in the Western Region), Alger.

[40] Escadafal, R. and Huete, A.R. (1991) Étude des propriétés spectrales des sols arides appliquée à l'amélioration des indices de végétation obtenus par télédétection. Comptes-rendus de l'Académie des Sciences de Paris, 312, 1385-1391.

[41] FAO (2012) Locust Watch—Desert Locust. Food and Agriculture Organization of the United Nations, Rome. http://www.fao.org/ag/locusts/en/activ/DLIS/satel/index.html 
Scientific Research Publishing (SCIRP) is one of the largest Open Access journal publishers. It is currently publishing more than 200 open access, online, peer-reviewed journals covering a wide range of academic disciplines. SCIRP serves the worldwide academic communities and contributes to the progress and application of science with its publication.

Other selected journals from SCIRP are listed as below. Submit your manuscript to us via either submit@scirp.org or Online Submission Portal.
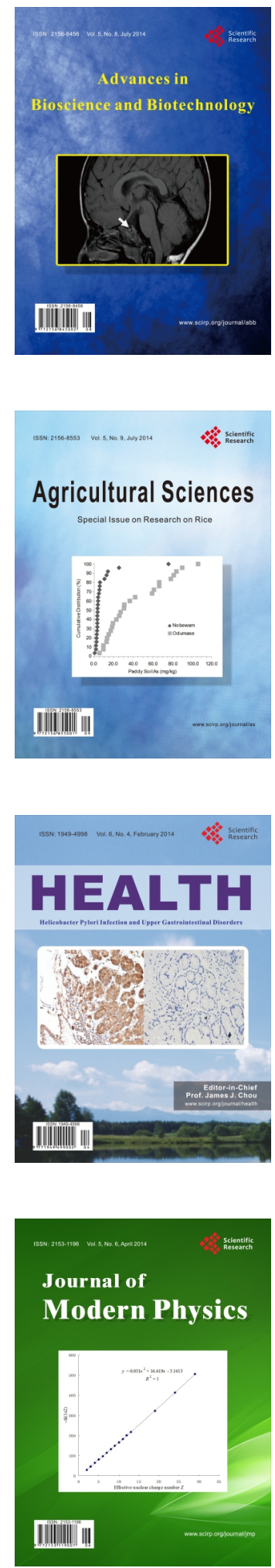
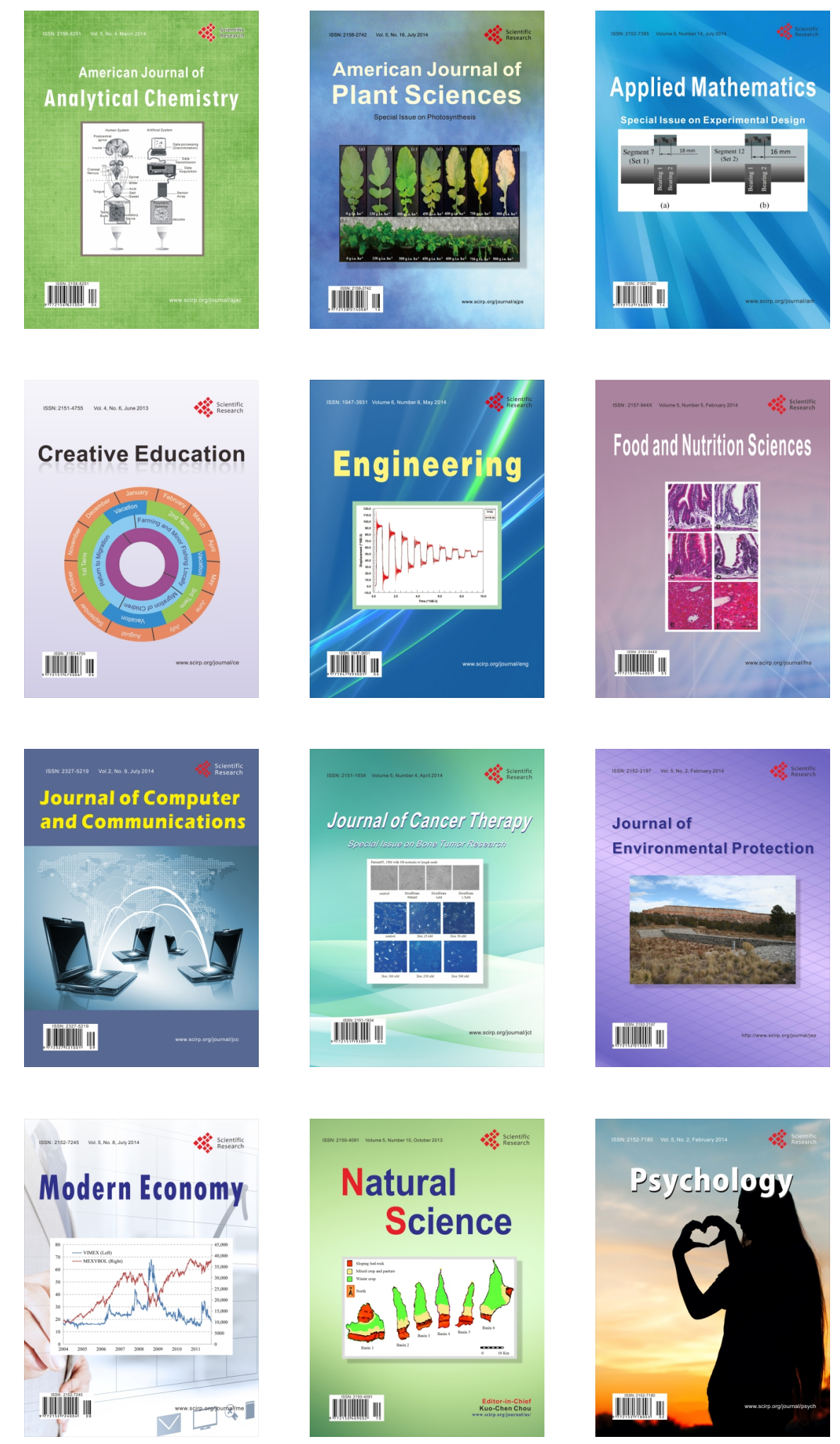